Proc. Estonian Acad. Sci. Geol., 2003, 52, 2, 113-127

\title{
Comparative study of dolomites of different genesis (Raikküla Formation, Silurian; Estonia)
}

\author{
Aada Teedumäe ${ }^{\mathrm{a}}$, Toivo Kallaste ${ }^{\mathrm{a}}$, and Tarmo Kiipli ${ }^{\mathrm{b}}$ \\ a Institute of Geology, Tallinn Technical University, Estonia pst. 7, 10143 Tallinn, Estonia; \\ teedumae@gi.ee \\ ${ }^{\mathrm{b}}$ Mining Institute, Tallinn Technical University, Kopli 82, 10412 Tallinn, Estonia
}

Received 5 March 2002, in revised form 22 October 2002

\begin{abstract}
Dolomites of the Upper Subformation of the Raikküla Formation (middle Llandovery), representing the deposits of the northern marginal part of carbonate shelf consisting of cyclically laminated limestone and lagoonal dolomite were studied. The formation of dolomite was investigated using X-ray diffraction, X-ray fluorescence, and titration analyses of the rocks of the same primary origin in nondolomitized sections and those affected by massive pervasive dolomitization. The $\mathrm{CaCO}_{3} / \mathrm{MgCO}_{3}$ ratio and lattice parameters of dolomites are in good agreement with the genesis. The primary lagoonal dolomite near the contact with limestone and dolomite in limestone have the most expanded lattice; the primary dolomite near the contact with pervasively dolomitized limestone has the parameters equal to the minimal for primary dolomites, registered in the centre of the layer; the most altered secondary dolomite is close to stoichiometric. The bimodal frequency distribution of the $\mathrm{Ca}$ content in dolomites of different genesis reflects the preferred levels of Ca uptake. The highest stoichiometry of the secondary (replacive) dolomite points to the role of recrystallization and crystallization rate. Compared to limestones dolomites are depleted in $\mathrm{Sr}$ and enriched in Mn. Major, minor, and trace element concentrations suggest that seawater (or modified seawater) was the dominant dolomitizing fluid. No evidence of hypersalinity or inflow of outside fluids has been observed. The direct relationship of dolomitization to the migrating inner shelf facies and regressive stages of the evolution of the Silurian Baltic Palaeobasin suggests early dolomitization.
\end{abstract}

Key words: Silurian, dolomitization, lithology, Palaeozoic dolomite, X-ray diffraction, Estonia.

\section{INTRODUCTION}

A complex study and interpretation of the chemical composition and X-ray diffractometry of the rocks of the same primary origin in nondolomitized and dolomitized sections enable a new approach to understanding the evolution of 
the process of dolomitization. Detailed investigations of the lithology, facies, and evolution of the Baltic Palaeobasin in the Silurian (Kaljo 1970; Jürgenson 1988; Nestor 1995, 1997; Nestor \& Einasto 1997) provide a favourable basis for the estimation of palaeoenvironmental factors. Studies on intensive spatial dolomitization of Silurian (Llandovery, Wenlock) primarily normal-marine calcareous sediments, which cross-cuts different facies and depositional sequences in central and western Estonia (Vishnyakov 1956; Jürgenson 1970; Kiipli 1983; Bityukova et al. 1996, 1998; Teedumäe 1992; Teedumäe et al. 1999, 2001), support the idea of its diagenetic origin with distinctions in details.

The present research constitutes a sequel to papers on massive pervasive dolomitization of Silurian rocks (Teedumäe et al. 1999, 2001). The main objectives of the research are (a) to give insight into the composition of dolomitized and nondolomitized rocks of the same genesis, (b) to reveal the correlation between variations of the composition and lattice parameters of dolomite, and (c) to establish the trends of alternation and evolution of the process of dolomitization of different rock types.

\section{GEOLOGICAL SETTING}

The dolomites studied in the Orgita and Mündi quarries (Fig. 1) belong to the Raikküla Formation of the Raikküla Regional Stage (middle Llandovery, Nestor 1997). The end of the Raikküla Age marks the end of a differentiation stage in the development of the Baltic Palaeobasin (Nestor \& Einasto 1997), which due to gradual regression evolved from epicontinental to gulf-like pericratonic sea. As a result, a full set of facies belts shifting southwestward was established. Shallowwater carbonate sediments dominated in the marginal part of the basin (Fig. 1). The middle Llandovery (Aeronian) ended with an extensive local sedimentation break and denudation. One area of denudation was situated in western Estonia, where the erosional hiatus increasing northwestwards cut the Raikküla Formation down to the lower layers. A more pronounced erosional break developed on the opposite (southern) flank of the Baltic Palaeobasin in eastern Lithuania, where the early and middle Llandovery deposits were subjected to denudation all over the carbonate shelf. The local character of nondeposition and the variable extent of deposition breaks suggest a tectonic origin of the upheaval, most probably induced by the beginning of the collision of the Laurentia and Baltica continents (Nestor \& Einasto 1997).

The Raikküla Formation is the northernmost unit of the Raikküla Stage. In a southerly direction it is laterally replaced by the Nurmekund and Saarde formations (Nestor 1997). The formation ranges in thickness from $30.5 \mathrm{~m}$ in the Valgu drill hole to $56 \mathrm{~m}$ in the Käru drill hole (Fig. 1). It represents the deposits of lagoonal and shoal facies belts, and consists of two shallowing-up sedimentation cycles starting with limestones (micritic, bioclastic, coral-stromatoporoid) and ending with argillaceous lagoonal dolostones. These cycles are treated as the Lower and 


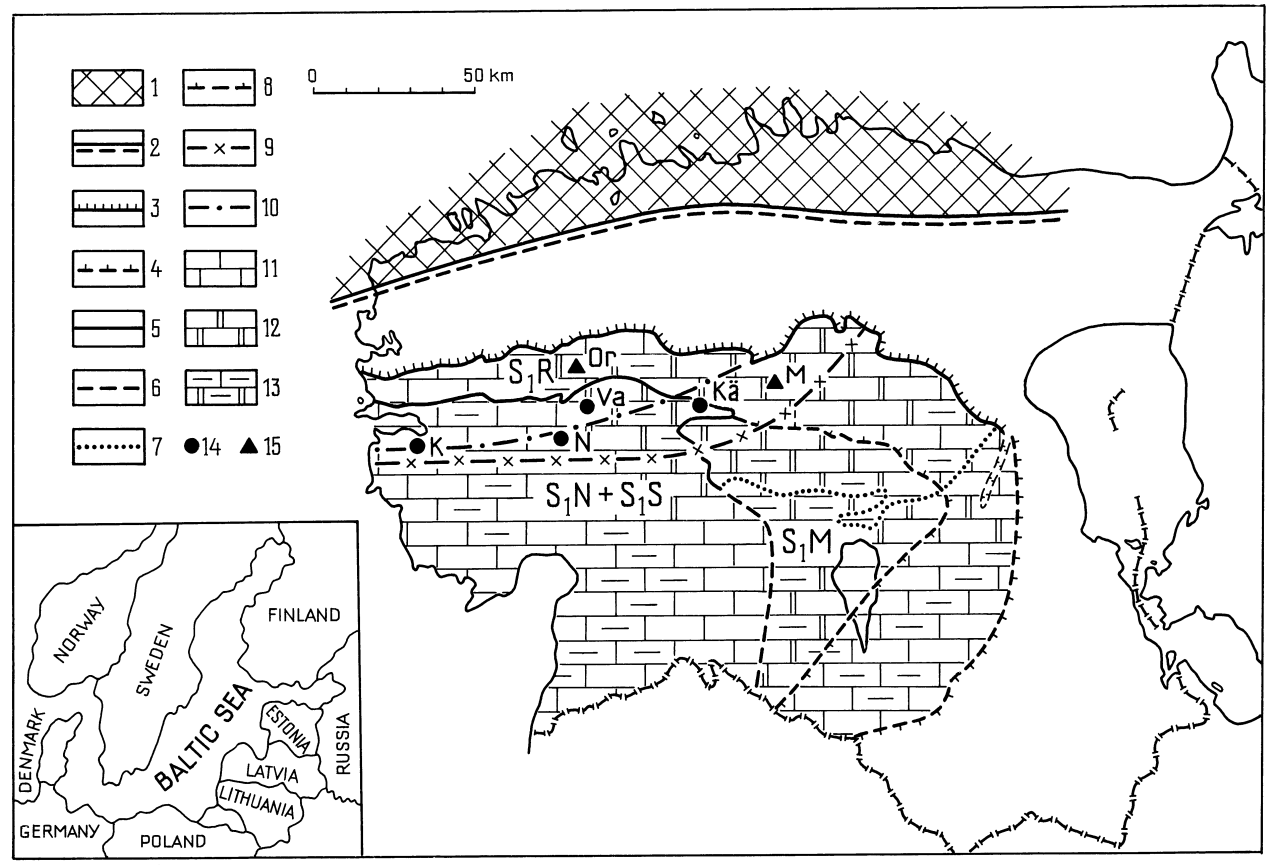

Fig. 1. Sketch map of the distribution and lithological composition of the Raikküla Stage. Contours 3-8 after Nestor (1997, fig. 67); lithology after Teedumäe et al. (2001, fig. 1). 1, land; 2, supposed shoreline; 3, contour of surface distribution of the Raikküla Stage; 4, contour of subsurface distribution of the Mõhküla Beds; 5, limit of the outcrop belt; 6 , limit of pre-Devonian erosion of the Mõhküla Beds; 7, margin of the Devonian cover; 8, extension limit of the Mõhküla Beds; 9, limit of the distribution of the Raikküla Formation; 10, northern limit of pervasive dolomitization; 11, limestone; 12, dolomite (dolostone); 13, argillaceous limestone and dolostone; 14, drill hole; 15, quarry; K, Kirikuküla drill hole; N, Nurme drill hole; Va, Valgu drill hole; Kä, Käru drill hole; Or, Orgita quarry; M, Mündi quarry; $S_{1} R$, Raikküla Formation; $S_{1} N+S_{1} S$, Nurmekund and Saarde formations; $\mathrm{S}_{1} \mathrm{M}$, Mõhküla Beds.

Upper Raikküla subformations (Nestor 1995). Within these cycles, a lower-rank cyclic alternation of biomicritic and bioclastic limestone and microlaminated argillaceous dolostone takes place. In the eastern and southern sections the deposits of the Upper Subformation are dolomitized.

Both studied sections belong to the upper sedimentary cycle (Upper Subformation). The Orgita quarry is situated outside the zone of dolomitization and represents a nonaltered section of sediments - limestones interbedding with lagoonal microlaminated dolostones (Table 1, Fig. 2). The Mündi quarry is situated in the zone of massive pervasive dolomitization, and the primarily normal-marine calcitic sediments, interbedding with lagoonal dolostones, are totally dolomitized (Table 2, Fig. 2). 
Table 1. Description of the section of the southern wall of the Orgita (Or) quarries (in descending order)

\begin{tabular}{c|c|c|c}
\hline $\begin{array}{c}\text { No. } \\
\text { of } \\
\text { layer }\end{array}$ & $\begin{array}{c}\text { Depth, } \\
\mathrm{m}\end{array}$ & Description & $\begin{array}{c}\text { Sample } \\
\text { No. and } \\
\text { depth, m }\end{array}$ \\
\hline
\end{tabular}

Big quarry

1-3 0.0-0.50 Light grey, massive, microlaminated, fine-crystalline, $\quad$ Or $1,0.10$ argillaceous dolomite

$4 \quad 0.50-0.62$ Light beige, thin wavy-bedded, fine-grained bioclastic

Or $2,0.60$ limestone (wackestone) with burrows, filled with greenish clayey material

$5 \quad 0.62-0.87$ Light grey horizontally-bedded, pelletal-fine-grained bioclastic

Or $3,0.75$ limestone (wackestone)

$6 \quad 0.87-0.97$ The same, with rough bedding planes $\quad$ Or 4, 0.90

$7 \quad 0.97-1.22$ The same, seminodular Or 5, 1.05

$8 \quad 1.22-1.30$ Grey, argillaceous, fine-crystalline dolomite with brownish $\quad$ Or $6,1.25$

$9 \quad 1.30-1.35 \quad$ Greyish-beige, plastic clay (metabentonite?)

$10 \quad 1.35-1.63$ Dolomite, the same as interval 1.22-1.35 m

Or $7,1.37$

11 1.63-1.88 Greenish-grey, argillaceous, microlaminated dolomite with $\quad$ Or 8, 1.75

12 1.88-2.08 Grey and beige-banded (1-3 mm), microlaminated, argillaceous Or 9, 2.00

$13 \quad 2.08-2.58 \quad$ Light yellowish-greenish-brownish spotted, massive, porous

Or $10,2.30$ (pores c. $1 \mathrm{~mm}$ ), microlaminated dolomite with brown dots

$14 \quad 2.58-2.71$ Grey, argillaceous, microlaminated dolomite with clayey

Or $11,2.60$ interlayers

15 2.71-3.61 Light grey, massive, porous (pores c. $1 \mathrm{~mm}$ ), microlaminated dolomite with brown dots and stripes and mud cracks

16 3.61-3.96 Greenish to grey, massive, microlaminated dolomite with brownish stripes, light grey spots and occasional pores

17 3.96-4.20+ Greyish-beige, microlaminated dolomite with occasional solution cavities of fossils and wavy, brownish stripes

Or $12,3.00$

Or $13,3.70$

Or $14,4.10$

\section{Small quarry}

$15 \quad 0.00-0.20$ Light grey, porous (pores c. $1-2 \mathrm{~mm}$ ), argillaceous dolomite

Or $16,0.10$ Light yellowish-grey, microlaminated, argillaceous dolomite with brownish stripes

$17 \quad 0.95-1.20$ Greyish-beige, microlaminated dolomite with brownish stripes

$18 \quad 1.20-1.50$ Yellowish, with grey spots, seminodular, biomicritic limestone (wackestone)

19 1.50-1.90+ Light grey, bioturbated limestone (wackestone) with dark grey burrows 
(a)

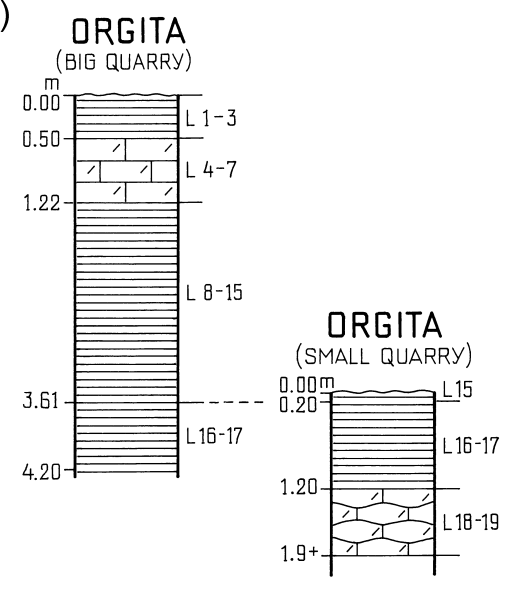

MÜNDI

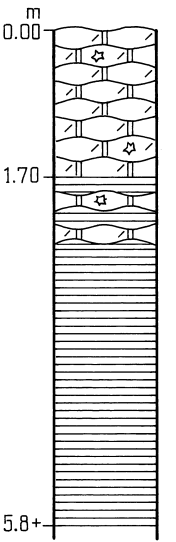

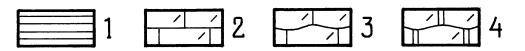

\& 5 L 1-3 6

(b)

Mündi quarry and Orgita big quarry
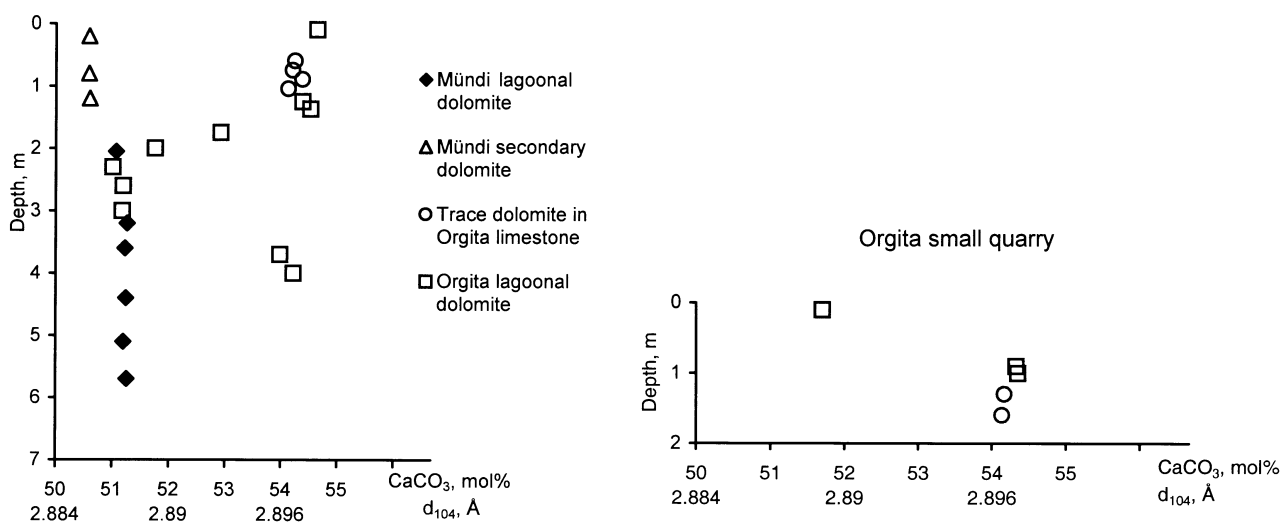

Fig. 2. Generalized geological sections (a) and variation of the $d_{104}$ value along the section (b). 1, Microlaminated dolomite; 2, horizontal-bedded bioclastic limestone; 3, seminodular bioclastic limestone; 4 , seminodular dolomite rich in debris of fossils; 5 , pores, caverns; 6 , numbers of layers (see Table 1). 
Table 2. Description of the section of the conserved wall of the Mündi (M) quarry (in descending order)

\begin{tabular}{|c|c|c|}
\hline $\begin{array}{c}\text { Depth, } \\
\mathrm{m}\end{array}$ & Description & $\begin{array}{c}\text { Sample } \\
\text { No. and depth, m }\end{array}$ \\
\hline \multirow[t]{3}{*}{$0.0-1.70$} & \multirow{3}{*}{$\begin{array}{l}\text { Grey, porous (pores of leached out debris up to } 2 \mathrm{~mm} \text { in dia- } \\
\text { meter, some caverns), fine-crystalline seminodular dolomite } \\
\text { rich in debris of fossils with brownish, and dark grey spots }\end{array}$} & M 9, 0.20 \\
\hline & & M 10, 0.80 \\
\hline & & M 8, 1.20 \\
\hline $1.70-3.05$ & $\begin{array}{l}\text { Light grey, microlaminated porous (pores up to } 1 \mathrm{~mm} \text { in dia- } \\
\text { meter) dolomite with bioclastic interlayers (up to } 10 \mathrm{~cm} \text { thick) } \\
\text { and mud cracks in the upper part }\end{array}$ & M 7, 2.05 \\
\hline $3.05-3.35$ & $\begin{array}{l}\text { Grey with dark stripes and dots, microlaminated dolomite } \\
\text { with three intercalations }(2-3 \mathrm{~cm}) \text { of plastic, yellowish clay }\end{array}$ & M 6, 3.20 \\
\hline $3.35-4.15$ & $\begin{array}{l}\text { Greenish-grey, microlaminated, argillaceous dolomite with } \\
\text { brownish spots and occasional pores (diameter up to } 5 \mathrm{~mm} \text { ) }\end{array}$ & M 5, 3.60 \\
\hline $4.15-4.20$ & Yellowish, plastic clay & - \\
\hline \multirow[t]{3}{*}{$4.20-5.77$} & \multirow{3}{*}{$\begin{array}{l}\text { Greenish-grey, microlaminated, thick-bedded }(0.4-0.6 \mathrm{~m}) \\
\text { dolomite. The content of argillaceous material varies by } \\
\text { layers }\end{array}$} & M 3, 4.40 \\
\hline & & M 2, 5.10 \\
\hline & & M 1, 5.70 \\
\hline $5.77-5.80+$ & Yellowish, plastic clay & - \\
\hline
\end{tabular}

\section{MATERIAL AND METHODS}

Twenty-nine samples (Table 3) were collected from the Orgita and Mündi quarries for the complex study of the chemical composition and X-ray diffractometry. Samples from the Orgita quarries (big and small, distance c. $50 \mathrm{~m}$ ) were collected bed by bed (Table 1) to correlate the sections of big and small quarries. Layers 1-16 are exposed in the big quarry, layers 15-19 in the small one. Layers 1-16 were distinguished by R. Einasto (personal unpublished materials), layers 17-19 were revealed in the bottom of the small quarry by the authors. From the Mündi quarry samples were collected more sparsely, by lithogenetical varieties, considering the changes inside the variety.

$\mathrm{CaO}, \mathrm{MgO}$, and insoluble residue were analysed by titration. $\mathrm{Fe}_{2} \mathrm{O}_{3}$ (total), $\mathrm{Mn}$, and $\mathrm{Sr}$ were analysed by the X-ray fluorescence method with the VRA-30 analyser using an X-ray tube with Mo anode at $50 \mathrm{kV}$ and $20 \mathrm{~mA}$. Calibration of $\mathrm{Mn}$ and $\mathrm{Fe}$ was based on internationally intercalibrated dolomite reference materials Es-4 and Es-11 without matrix corrections. In calibration of $\mathrm{Sr}$ some additional silicate and limestone reference materials were used and, accordingly, matrix corrections (Compton scattering method) were applied. The precision of analyses was determined from 10 replicate measurements: $\mathrm{Fe}_{2} \mathrm{O}_{3} \pm 0.005 \%$, $\mathrm{MnO} \pm 0.005 \%, \mathrm{Sr} \pm 2 \mathrm{ppm}$.

XRD measurements were carried out on a diffractometer HZG4, using $\mathrm{Fe}$-filtered Co radiation. The rock powder was mixed in a mortar with $\mathrm{Si}$ in a ratio of $8: 2$, some drops of ethanol were added, and the mixture was evenly spread on a glass slide. The measured angular range $32-38^{\circ} 2 \theta$ revealed the 104 


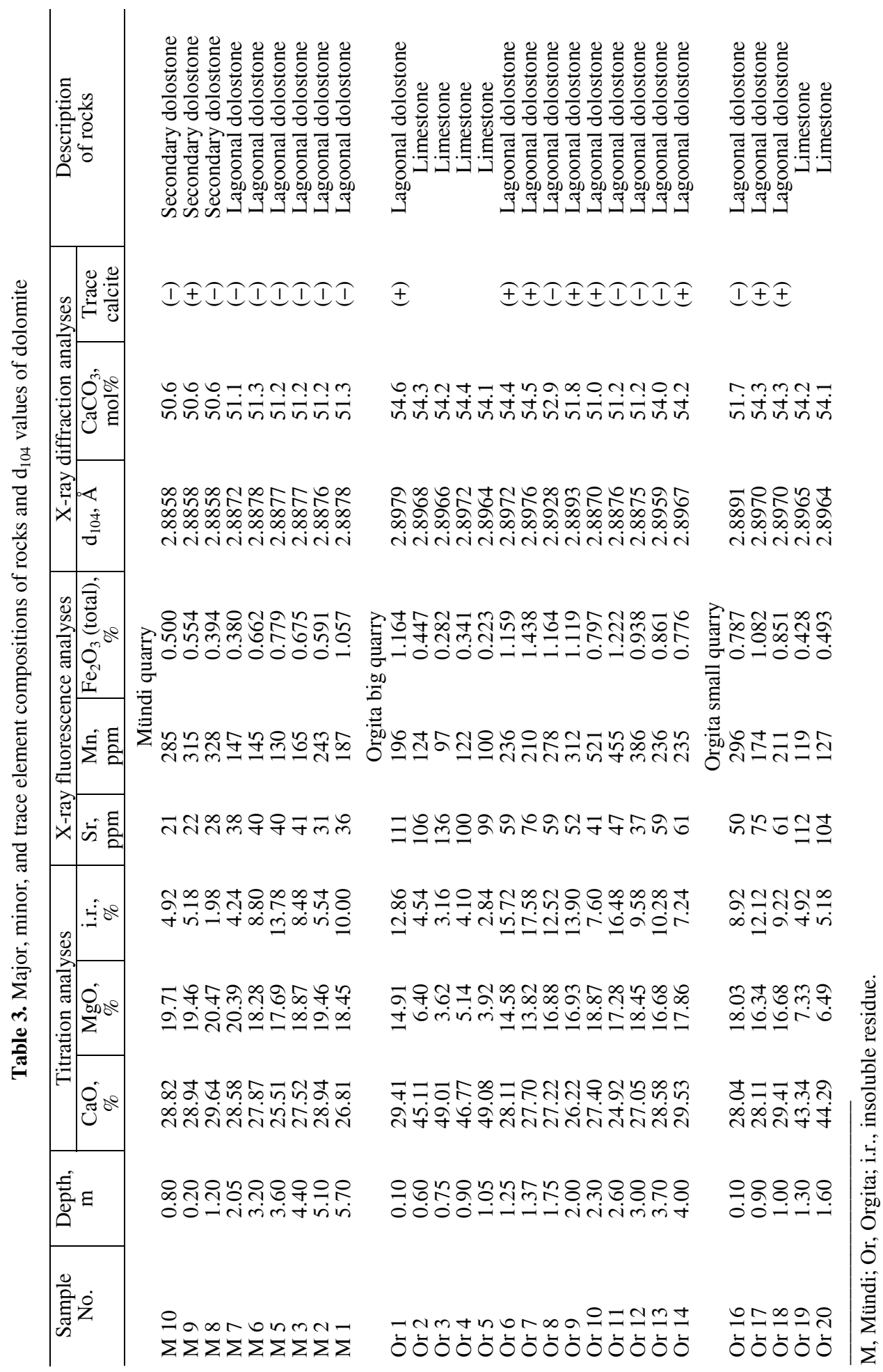


reflection of dolomite $\left(\mathrm{d}_{104}\right)$ and calcite and 111 reflection of $\mathrm{Si}$. The positions of reflections were calculated as weighted average. The instrumental shift was corrected according to the Si reflection (3.1355 $\mathrm{A})$.

The molar concentration of $\mathrm{CaCO}_{3}\left(m_{\mathrm{Ca}}\right)$ in dolomite (Table 3$)$ was calculated using its linear dependence on lattice parameters (e.g. Lippmann 1973). The formula

$$
m_{\mathrm{Ca}}=\frac{\left(\mathrm{d}_{104}-2.8840\right)}{0.003}+50
$$

expresses the linear dependence of $\mathrm{d}_{104}$ of dolomite with respect to the fix-point of ideal stoichiometric dolomite. The value $2.8840 \AA$ for $d_{104}$ of ideal dolomite was calculated (Teedumäe et al. 1999) on the ground of the composition of two standards, Es-4 (Estonia) and SI-1 (USSR).

\section{RESULTS AND DISCUSSION}

The $\mathbf{d}_{\mathbf{1 0 4}}$ value of dolomite in the studied rocks varies from 2.8858 to $2.8976 \AA$ (Table 3, Fig. 2). It is higher than that of ideal dolomite (2.8840 $\AA$, Teedumäe et al. 1999) and varies by different rock types: lagoonal dolostone (Orgita and Mündi), secondary (replacive) dolostone (Mündi), and limestone (Orgita).

The $d_{104}$ value of the dolomite of lagoonal origin in the Orgita quarry is the highest $(>2.897 \AA$ ) near the contact with limestone. It decreases towards the centre of the layer to $2.8870-2.8875 \AA$ (Table 3, Fig. 2). The same regularities have been found in previous studies (Vingisaar \& Utsal 1978; Kiipli 1983; Kallaste \& Kiipli 1995). This suggests that the Ca-rich environment breaks the process of crystallographic ordering of dolomite in contacting sediments. The abrupt change in the content of insoluble residue on the contact of limestone and dolostone (Table 3) reflects the transition from lagoonal to marine environment, and vice versa. Due to different hydrodynamics (quiet or active water) the transition is always abrupt, even in case of short-time changes in facies conditions as in the Mündi quarry, where thin layers $(5-10 \mathrm{~cm})$ of lagoonal dolomite and secondary dolomite (originally bioclastic limestone) are altering (Table 2, interval 1.7-3.05 m). This reflects lower-rank cyclicity within higher-rank cyclicity.

The $\mathrm{d}_{104}$ value of dolomite in the lagoonal dolostone of the Mündi quarry is rather constant, varying between 2.8872 and $2.8878 \AA$ (Table 3 ). It equals to that of unaltered dolomite of the Orgita quarry in the middle part of the section (Fig. 2), without any change near the contact with the overlying secondary dolomite. Most likely this is due to early diagenetic dolomitization of the overlying calcitic sediments, which has favoured the ordering of Ca-rich poorly ordered dolomite of the supposedly not totally lithified upper part of lagoonal sediment.

The limestone of the Orgita quarry contains $3.62-7.33 \% \mathrm{MgO}$, which is quite characteristic of the shallow-water Silurian calcareous sediments of the Baltic Palaeobasin (Teedumäe 1986). Limestones of higher purity ( $\mathrm{MgO}$ less than 3\%) 
are of restricted distribution. The $\mathrm{d}_{104}$ value of the dolomite coexisting with calcite in limestone (2.8964-2.9872 $\AA$ ) is equal to that of the dolomite in lagoonal dolostone near the contact with the limestone (Table 3, Fig. 2).

The secondary dolomite of the Mündi quarry, originating from the normalmarine calcitic sediments, has the lowest and constant $d_{104}$ value of $2.8858 \AA$ among all studied rock types (Table 3, Fig. 2).

The calculated and measured $\mathrm{d}_{104}$ values are in agreement with the results of titration analyses. This shows that most likely additional $\mathrm{Ca}$ is bound in dolomite, resulting in the expansion of lattice parameters. The bimodal distribution of $\mathrm{Ca}$ becomes evident in the XRD measurements (Fig. 2) which form two general groups, clustering between 2.885 and $2.890 \AA\left(50-52\right.$ mol\% $\left.\mathrm{CaCO}_{3}\right)$, and 2.896 and $2.898 \AA\left(54-55 \mathrm{~mol} \% \mathrm{CaCO}_{3}\right)$ and correlating well with the genetical types of dolostone (Searl 1994; Kallaste \& Kiipli 1995). The first group (Fig. 2) includes the dolomite of secondary origin $\left(50.6 \mathrm{~mol} \% \mathrm{CaCO}_{3}\right)$, the lagoonal dolomite near the contact with it and in the central part of the layer (51.1$51.8 \mathrm{~mol} \% \mathrm{CaCO}_{3}$ ). The second group comprises the lagoonal dolomite near the contact with limestone and trace dolomite in limestone (54.2-54.5 mol\% $\mathrm{CaCO}_{3}$ ).

Such clustered ranges of $\mathrm{Ca} / \mathrm{Mg}$ variation in dolomite occur as modal compositions reflecting the preferred levels of $\mathrm{Ca}$ uptake. The stability of the lattice of Ca-rich dolomite depends on the character of the ordering of $\mathrm{Ca}$ ions within $\mathrm{Mg}$ layers. Sedimentary Ca-rich, initially metastable, poorly ordered dolomite commonly tends to "mature" (Vahrenkamp \& Swart 1994) by recrystallization subsequently to its initial precipitation. Patterns of substitution, in which $\mathrm{Ca}$ ions are evenly distributed within $\mathrm{Mg}$ layers, are likely to be more stable than those in which lattice strain is unevenly distributed within Mg layers. Searl (1994) suggests that there is an underlying mineralogical constraint on dolomite compositions, which may drive recrystallization.

The results of the present and previous studies (Teedumäe et al. 1999, 2001) show that the secondary (replacive) dolomite in the zone of massive pervasive dolomitization is the most completely ordered dolomite in Estonia. This may point, besides the environmental characteristics and total recrystallization, to the role of the crystallization rate, as very slowly growing crystals are closer to the stoichiometric composition (Morrow 1982).

The content of $\mathbf{F e}$ compounds $\left(\mathrm{Fe}_{2} \mathrm{O}_{3}\right.$ (total)) shows a positive correlation with the content of insoluble residue (Fig. 3) for all types of studied dolostones (primary and secondary) and also limestone. This indicates the primary sedimentary, predolomitization origin of $\mathrm{Fe}$ and allows us to suggest the internal source (seawater or modified one) of $\mathrm{Mg}$ and early process of pervasive dolomitization. Later fluids could have changed the primary balance of $\mathrm{Fe}$ as observed in secondary dolomites near the tectonic disturbances. These dolomites have a higher Fe content, which correlates with the content of Mg (Bityukova et al. 1996, 1998).

The concentration of $\mathbf{M n}$ is comparatively low, ranging between 130 and $521 \mathrm{ppm}$. It has no correlation with insoluble residue and is the lowest for secondary altered lagoonal dolomite (Mündi). The poorly ordered unaltered lagoonal dolomite (Orgita) displays a covariance of Mn with the increasing stoichiometry (Fig. 4). 


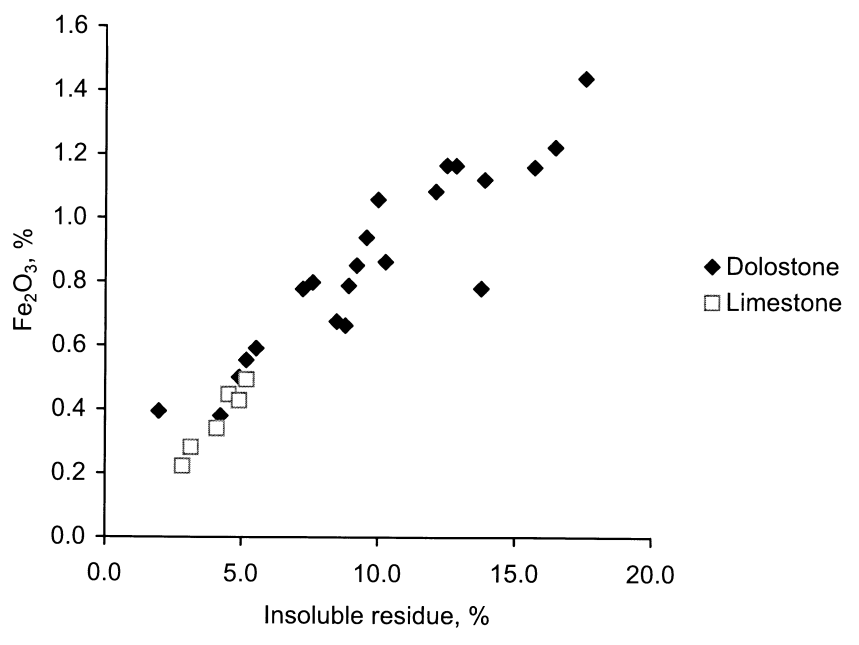

Fig. 3. Correlation of the content of $\mathrm{Fe}_{2} \mathrm{O}_{3}$ (total) and insoluble residue.

This is probably due to the varying primary Mn availability and Eh (Bernasconi 1994) during the dolomite formation. Mn as highly soluble in the anoxic environment could be incorporated into the dolomite lattice. In the present case the impact of $\mathrm{Mn}$ concentration on dolomite structure is below the precision of the method (Teedumäe et al. 2001). For the other types of dolomite no covariance is observed.

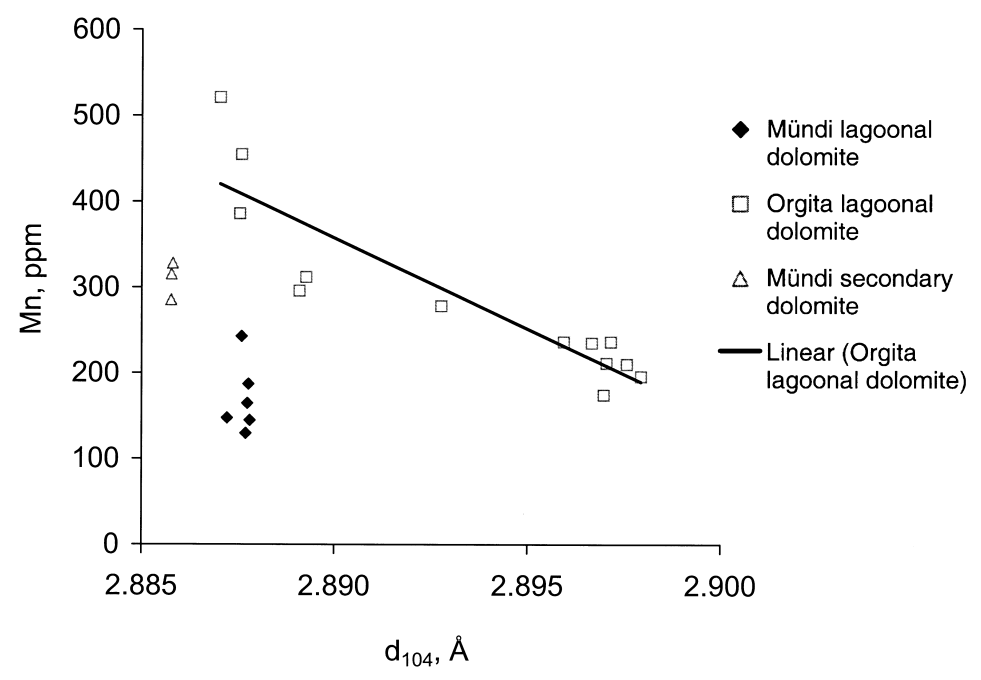

Fig. 4. Correlation of the Mn concentration and $d_{104}$ value. 
The content of $\mathbf{S r}$ is low, varying between 21 and $75 \mathrm{ppm}$ (Table 3). It has a positive correlation with the molar concentration of $\mathrm{CaCO}_{3}$ (Table 3) and stoichiometry (Fig. 5) of dolomites, displaying optimal intake of $\mathrm{Sr}$ and the observable dependence on the evidence of recrystallization. The concentrations (21-28 ppm) are lowest in the secondary dolomite of fully recrystallized and dolomitized, primarily calcitic sediment, highest $(52-76 \mathrm{ppm})$ in the unaltered primary (lagoonal) dolomite. The dolomite, affected by dolomitization of primary lagoonal dolostone (Mündi), and that in the middle part of the primary lagoonal dolostone layer (Orgita) have equal concentrations between 31 and $47 \mathrm{ppm}$. The concentration of $\mathrm{Sr}$ is evidently related to the process of dolomite formation (Teedumäe et al. 2001). Dissolution and recrystallization result in depleted $\mathrm{Sr}$ concentrations in dolomite. Extremely high Sr concentrations (400-1000 ppm) have been observed in case of deposition in evaporative reflux during rapid crystallization (Kupecz \& Land 1994). The Silurian replacive dolomites in Estonia are depleted in Sr (Teedumäe et al. 1999, 2001), which indicates a slow rate of dolomitization.

The above-presented sedimentological evidence and analytical data suggest a syndepositional (primary) origin of the microlaminated lagoonal dolostone of the Orgita quarry: it contacts with normal-marine limestones, primary lithological characteristics (microlamination, mud cracks, etc.) are well preserved, vertical variation of the $\mathrm{d}_{104}$ value of mineral dolomite along the section corresponds to natural changes in the depositional environment induced by the cyclical development of the palaeobasin. Microlamination is due to episodic deposition of at least one of the sediment constituents (Ricken \& Eder 1991), most probably organic matter. The potential importance of organic (algal) matter in the

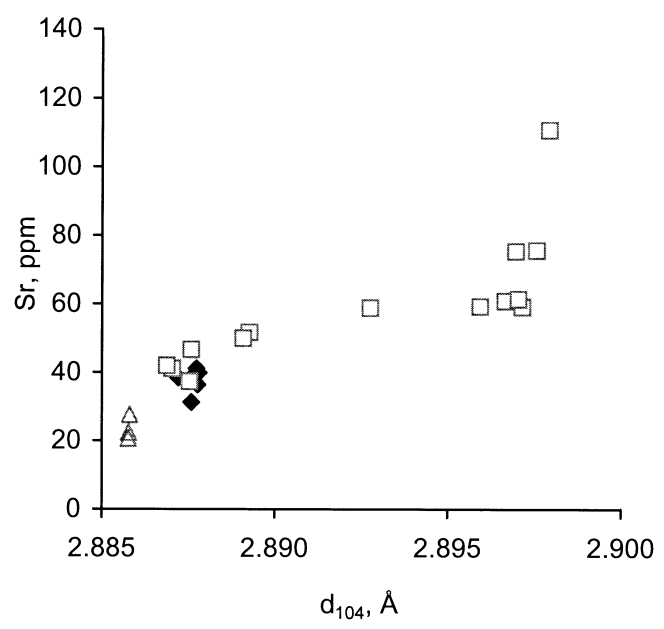

Fig. 5. Correlation of the $\mathrm{Sr}$ concentration and $d_{104}$ value. For legend see Fig. 4 . 
precipitation of dolomite has been invoked by a number of researches (Garrison et al. 1984; Baker \& Burns 1985; Slaughter \& Hill 1991). The results of laboratory experiments (Warthman et al. 2000) have demonstrated that sulphate-reducing bacteria, grown in a synthetic liquid medium, produced nonstoichiometric dolomite during 30 days' incubation at $30^{\circ} \mathrm{C}$. The role of anaerobic bacteria might have been significant in the formation of lagoonal dolomitic deposits in semi-isolated marginal-marine settings of the middle Llandovery. The area of the present distribution of unaltered lagoonal dolostones of the Raikküla Formation is limited to the northernmost part of the outcrop belt (Fig. 1). To the south and east of it stays the area of pervasively dolomitized rocks, which is expressed in the dolomites of the Mündi quarry.

Similar concentrations of minor and trace elements attribute the formation of the studied primary and secondary dolomites to the seawater (normal or mixed) environment. No evidence of hypersalinity or inflow of outside fluids is observed.

Massive pervasive dolomitization of Silurian rocks associates with the regressive stages of the evolution of the Baltic Palaeobasin. It is related to the inner shelf facies zone (Teedumäe et al. 1999, 2001) which migrated basinward and landward in response to the cyclic fluctuation of sea level and oscillation of the shoreline in the middle Llandovery. Such a direct spatio-temporal relationship of dolomitization with the evolution of the sedimentary basin is the principal argument for early dolomitization. The late Llandovery limestones (Adavere Stage), overlapping the middle Llandovery dolomites (Raikküla Stage) in the Kirikuküla, Nurme, and Valgu drill cores also support this statement, limiting the time span between the formation and dolomitization of sediments within the Raikküla Age.

The well-preserved primary sedimentary and biogenic structures of secondary dolomite also indicate that dolomitization occurred shortly after deposition. Late dolomitization under burial conditions obliterates finer sedimentary and biogenic structures (such as microlamination, skeletal hard parts, etc.) and primary bedding is recognizable with difficulty.

The localization of the migrating zone of dolomitization depends on a great number of geochemical and physical factors, required for the creation of the dolomitizing environment. The absence of one or some of them excludes the process and sections of similar cycles (parasequences), situated nearby, may differ in terms of dolomitization. This is demonstrated in the present study on the example of the Orgita section, unaffected by dolomitization, and the dolomitized Mündi section. The growth of the degree of the crystallographic ordering of the primary lagoonal dolomite near the contact with the overlapping secondary dolomite (Mündi) results from dolomitizing fluids. As it is not accompanied by lithological changes, the dolomitization by all probability preceded total lithification of the underlying sediment. An analogous phenomenon is followed in the Orgita unaltered section on the contact of lagoonal dolomite with the overlapping limestone, where the impact of the overlying calcitic sedimentation has lowered the degree of crystallographic ordering of contacting dolomite. 


\section{CONCLUSIONS}

The studied rocks have formed in different sedimentary and diagenetic settings. They belong to the upper of the two cyclically shallowing-up sedimentation cycles of the Raikküla Formation (Upper Subformation) and represent shallowwater carbonate sediments of the Middle Estonian Confacies Belt of the Baltic Silurian Palaeobasin. The rocks are pervasively dolomitized in the southern offshore area of their distribution, which corresponds to the inner shelf facies zone.

The $\mathrm{CaCO}_{3} / \mathrm{MgCO}_{3}$ ratio and lattice parameters of mineral dolomite are in good agreement with the genesis. The primary (syngenetic) dolomite near the contact with limestone and in limestone has the most expanded lattice. The lattice parameters of the primary dolomite near the contact with the secondary dolostone are equal to the minimal for primary dolomites, registered in the centre of the layer. The most altered replacive dolomite is the most stoichiometric.

The bimodal frequency distribution of the Ca content in dolomites of different genesis reflects the preferred levels of $\mathrm{Ca}$ uptake. The corresponding values of $\mathrm{mol} \% \mathrm{CaCO}_{3}$ are 50-52 and 54-55 (Fig. 2).

The secondary (replacive) dolomite is the most completely ordered. This points, besides the environmental characteristics, to the role of the crystallization rate, as very slowly growing crystals are closer to the stoichiometric composition.

Fe concentration has a positive linear correlation with insoluble residue, which shows the pre-dolomitization origin of the former. Persistance of this relationship through all types (primary and secondary dolomites and limestone) of the studied rocks is inconsistent with the idea of the later inflow of dolomitizing fluids from the outside.

Compared to limestones dolomites are depleted in $\mathrm{Sr}$ and enriched in $\mathrm{Mn}$. The differences between primary and secondary dolomites are small. Dissolution and recrystallization have resulted in the lowest concentrations of $\mathrm{Sr}$ in totally replaced dolomites. The late Llandovery limestones, overlapping the middle Llandovery dolomites in the Kirikuküla, Nurme, Virtsu, and Valgu drill holes, indicate early dolomitization, determining the time span between the formation and dolomitization of sediments within the Raikküla Age.

\section{ACKNOWLEDGEMENTS}

The present study was carried out in the Institute of Geology at Tallinn Technical University and was supported by the governmental target funding project No. 0332088s02 "Evolution of the composition and properties of rocks in the Baltic sedimentary cover: geochemical, mineralogical, and petrophysical aspects and modelling". The titration analyses were performed in the laboratory of the Geological Survey of Estonia. 
We are grateful to K. Kirsimäe for the constructive review of the paper, D. Kaljo, H. Nestor, and R. Einasto for useful comments, P. Männik for the help in sampling, H. Kukk for linguistic corrections, and K. Ronk for drawing figures.

\section{REFERENCES}

Baker, P. A. \& Burns, S. J. 1985. The occurrence and formation of dolomite in organic-rich continental margin sediments. Bull. Am. Ass. Petrol. Geol., 69, 1917-1930.

Bernasconi, S. M. 1994. Geochemical and microbial controls on dolomite formation in anoxic environments: a case study from the Middle Triassic (Ticino, Switzerland). In Contributions to Sedimentology, Vol. 19 (Füchtbauer, H., Lisitzyn, A. P., Millimann, J. D. \& Seibold, E., eds.), pp. 1-81. Schweizerbart'sche Verlagsbuchhandlung (Nägele u. Obermiller), Stuttgart.

Bityukova, L., Shogenova, A., Puura, V., Saadre, T. \& Suuroja, K. 1996. Geochemistry of major elements in Middle Ordovician carbonate rocks: comparative analysis of alternation zones, North Estonia. Proc. Estonian Acad. Sci. Geol., 45, 78-91.

Bityukova, L., Shogenova, A. \& Götze, H.-J. 1998. Influence of chemical composition on petrophysical properties of Early Paleozoic carbonate rocks in Estonia. Phys. Chem. Earth, 23, 309-316.

Garrison, R. E., Kastner, M. \& Zenger, D. H. 1984. Dolomites of the Monterey Formation and other organic-rich units. Soc. Econ. Paleont. Mineral., Pacific Section, 41.

Jürgenson, E. 1970. Secondary alternation of rocks. In Silur Éstonii (Kaljo, D., ed.), pp. 96-100. Valgus, Tallinn (in Russian).

Jürgenson, E. 1988. Osadkonakoplenije v silure Pribaltiki. Valgus, Tallinn (in Russian).

Kaljo, D. 1970. Raikküla Stage. In Silur Éstonii (Kaljo, D., ed.), pp. 221-232. Valgus, Tallinn (in Russian).

Kallaste, T. \& Kiipli, T. 1995. Discrete dolomite phases in carbonate rocks: results of the mathematical treatment of X-ray diffraction peaks. Proc. Estonian Acad. Sci. Geol., 44, 211-220.

Kiipli, T. 1983. On the genesis of Ordovician and Silurian dolomites at the contact with Devonian deposits. ENSV TA Toim. Geol., 32, 110-117 (in Russian).

Kupecz, J. A. \& Land, S. L. 1994. Progressive recrystallization and stabilization of early-stage dolomite: Lower Ordovician Ellenburger Group, west Texas. In Dolomites (Purser, B., Tucker, M. \& Zenger, D., eds.), pp. 255-282. Blackwell Scientific Publications, Oxford.

Lippmann, F. 1973. Sedimentary Carbonate Minerals. Springer-Verlag, Berlin.

Morrow, D. W. 1982. Diagenesis 2. Dolomite - part 2. Dolomitization models and ancient dolostones. Geosci. Canada, 9, 95-107.

Nestor, H. 1995. Comments to the modernized Silurian correlation chart of Estonia and Latvia. Geologija, 17, 88-95.

Nestor, H. 1997. Raikküla Stage. In Geology and Mineral Resources of Estonia (Raukas, A. \& Teedumäe, A., eds.), pp. 94-95. Estonian Academy Publishers, Tallinn.

Nestor, H. \& Einasto, R. 1997. Ordovician and Silurian carbonate sedimentation basin. In Geology and Mineral Resources of Estonia (Raukas, A. \& Teedumäe, A., eds.), pp. 192-204. Estonian Academy Publishers, Tallinn.

Ricken, W. \& Eder, W. 1991. Diagenetic modification of calcareous beds - an overview. In Cycles and Events in Stratigraphy (Einsele, G., Ricken, W. \& Seilacher, A., eds.), pp. 430-449. Springer-Verlag, Berlin.

Searl, A. 1994. Discontinuous solid solution in Ca-rich dolomites: the evidence and implications for the interpretation of dolomite petrographic and geochemical data. In Dolomites (Purser, B., Tucker, M. \& Zenger, D., eds.), pp. 361-376. Blackwell Scientific Publications, Oxford. 
Slaughter, M. \& Hill, R. J. 1991. The influence of organic matter in organogenic dolomitization. J. Sedim. Petrol., 61, 296-303.

Teedumäe, A. 1986. Industrial types of carbonate rocks of the Estonian SSR. Proc. Acad. Sci. Estonian SSR Geol., 35, 27-34 (in Russian).

Teedumäe, A. 1992. Possibilities of the application of carbonate rocks of the Raikküla Formation (Silurian, Estonia). Proc. Estonian Acad. Sci. Geol., 41, 63-72.

Teedumäe, A., Kallaste, T. \& Kiipli, T. 1999. Dolomites of the Muhu Formation (Silurian) in mainland Estonia: aspects of dolomitization, properties, and prospects of utilization. Proc. Estonian Acad. Sci. Geol., 48, 213-227.

Teedumäe, A., Kallaste, T. \& Kiipli, T. 2001. Aspects of the dolomitization of the Mõhküla Beds (Silurian, Estonia). Proc. Estonian Acad. Sci. Geol., 50, 190-205.

Vahrenkamp, V. C. \& Swart, P. K. 1994. Late Cenozoic dolomites of the Bahamas: metastable analogues for the genesis of ancient platform dolomites. In Dolomites (Purser, B., Tucker, M. \& Zenger, D., eds.), pp. 133-154. Blackwell Scientific Publications, Oxford.

Vingisaar, P. \& Utsal, K. 1978. On Estonian Palaeozoic rockforming carbonate minerals. Sov. geologiya, 12, 107-115.

Vishnyakov, S. G. 1956. Genetic types of dolomitic rocks in the northwestern margin of the Russian Platform. Tr. geol. in-ta AN SSSR, 4, 209-255 (in Russian).

Warthman, R., van Lith, Y., Vasconcelos, C., Mc Kenzie, J. A. \& Karpoff, A. M. 2000. Bacterially induced dolomite precipitation in anoxic culture experiments. Geology, 28, 1091-1094.

\section{Raikküla kihistu (Silur) eritekkeliste dolomiitide võrdlev uurimus}

\section{Aada Teedumäe, Toivo Kallaste ja Tarmo Kiipli}

Dolomiidistumisest puutumata ja sekundaarselt dolomiidistunud samatekkeliste kivimite - tsükliliselt vahelduvakihiliste laguunsete dolo- ja lubjakivide koostis ning neis sisalduva dolomiidi kristallvõre parameetrid võimaldavad selgitada dolomiidi tekketingimusi. Dolomiidi $\mathrm{CaCO}_{3}$ ja $\mathrm{MgCO}_{3}$ molaarne suhe ning võreparameetrid on otseses seoses geneesiga: kõige laiendatum võre on lubjakivis esineval kaltsiumirikkal dolomiidil ja primaarsel (laguunitekkelisel) dolomiidil lubjakivi kontakti lähedal ( $c a 0,5-0,7 \mathrm{~m}$ ulatuses); sekundaarse dolokiviga kontakteeruva primaarse dolomiidi võreparameetrid on võrdsed viimase minimaalväärtustega; sekundaarse dolomiidi kristallvõre on ideaalilähedane; see näitab, et täiusliku võrega dolomiidi tekke eelduseks on täielik ümberkristalliseerumine. Geoloogiline, sedimentoloogiline ja geokeemiline andmestik kinnitab, et nii primaarne laguunne kui ka sekundaarne lausaline dolomiit on kujunenud merelises keskkonnas. Mingeid ilminguid ülisoolsuse või basseiniväliste lahuste sissevoolu kohta täheldatud ei ole. Laguunitekkeliste dolokivide kontaktialal nii lubjakivide kui ka sekundaarsete dolokividega ilmnevate dolomiidi võreparameetrite muutuste põhjal otsustades toimus keskkonna muutus tõenäoliselt enne lamava sette täielikku kivistumist. See toetab seisukohta, et algne lubisete dolomiidistus varase diageneesi staadiumis. 